() К. О. Чепурна, к.т.н., доцент, А. В. Кабиш, магістр, КП। ім. Ігоря Сікорського, Київ, Україна

\title{
ВПЛИВ ХАРАКТЕРИСТИК ШРИФТУ НА ЯКІСНІ ПОКАЗНИКИ ПОЛІГРАФІЧНОЇ ПРОДУКЦІї, ВИГОТОВЛЕНОЇ ЦИФРОВИМ ДРУКОМ
}

\section{Досліджено вплив зміни характеристик шрифту на якість відтворення текстової інформації цифровим друком.}

\section{Ключові слова: характеристики шрифту; читабельність; показники якості; трекінг; масштабування символу по горизонталі; оригінал-макет.}

\section{Постановка проблеми}

Під час створення оригіналмакету будь-якого видання значна увага приділяється вибору шрифтового оформлення. Вдало підібрані параметри шрифту, такі як кегль, гарнітура, пропорційність висоти знака до його ширини, ритм форми, насиченість очка літер, відношення кольору шрифту до кольору фону; а також параметри сторінки складання (ширина/висота сторінки складання, інтерліньяж, форма рядків) $€$ запорукою створення красивого, оригінального, зручного з точки зору сприйняття інформації макету видання.

Вибір шрифтового оформлення для створення оригінал-макету залежить від характеру інформації, типу та призначення видання. Часто виникає потреба у розміщенні значного об'єму тексту на мінімально можливій площі задруковуваного матеріалу без втрати якісних показників сприйняття інформації споживачами, таких як читабельність, розбірливість, зручність. Одним з найпотужніших методів впливу на шрифтове оформлення під час верстання оригінал-макету $є$ зміна характеристик трекінгу та масштабування символів по горизонталі, що дозволяє збільшити обсяг текстової інформації на сторінці складання, і, відповідно, знизити витрати задруковуваних матеріалів. 3 іншого боку, застосування щодо літер ущільнення, змінення трекінгу негативно може відобразитися на читабельності та сприйнятті текстової інформації. Найчастіше ця проблема виникає під час підготовки малотиражних науково-методичних, інформаційних та акцидентних видань, які виготовляються цифровим друком (електрофотографічним або струминним).

Сучасна тенденція оформлення текстової інформації полягає у виборі незвичної, оригінальної гарнітури з метою приваблення читачів, але дуже часто такий вибір дизайнерів/верстальників не відповідає можливостям пристрою виведення. У результаті на відбитках наявні дефекти

(c) $2017 \mathrm{p}$. 
відтворення тексту, такі як пропадання/розтискування штрихів, змазування/злиття символів тощо.

Для забезпечення якісного відтворення текстової інформації цифровим друком необхідно знати, у яких межах можна проводити зміну параметрів шрифтового оформлення (трекінг, кернінг, масштабування символів по горизонталі).

\section{Аналіз попередніх досліджень}

Сприйняття шрифтового оформлення текстової інформації характеризується такими показниками як розбірливість, читабельність та зручність читання. Розбірливість характеризує легкість розпізнавання окремих знаків, у той час як читабельність це розрізнення слів і текстових блоків, зумовлена способом їх розміщення на сторінці; зручність читання - більш широке поняття, і залежить не лише від параметрів шрифтового оформлення, але і від призначення видання та характеру інформації, об'єктивним критерієм зручності читання є швидкість читання [1-3].

Існує цілий ряд методик, за допомогою яких можна оцінити швидкість читання. Основні критерії, які враховуються: загальна кількість слів у тексті, середня довжина речення і кількість символів у слові. Розрахунок проводять за індексом туманності Ганнінга або Колемана-Ліау, формулою Флеша або ФлешаКінкейда [4].

Дослідження шрифтового оформлення видань базуються, як правило, на виборі геометричних показників шрифтів відповідно до жанру, характеру текстової інформації, виду продукції (книга, журнал, газета, фотоальбоми тощо), споживацької аудиторії (діти, фахівці галузі тощо) $[2,5]$.

у роботах [6-8] проведені дослідження спрямовані на виявлення найбільш вдалих геометричних комбінацій під час створення/вибору шрифтового оформлення $з$ метою забезпечення максимальної читабельності.

\section{Мета роботи}

Визначення впливу характеристик шрифту, таких як гарнітура, кегль, трекінг, масштабування символів по горизонталі та їх комбінації на читабельність та якість відтворення текстової інформації на відбитках струминного та електрофотографічного друку задля розробки пропозицій щодо змін параметрів шрифтового оформлення видання без втрати якості друкованої продукції.

\section{Результати проведених досліджень}

Проводили дослідження зміни параметрів шрифту шляхом ущільнення очка літери та трекінгу, що дозволяє змінити обсяг текстової інформації в рядку, і відповідно зменшує кількість сторінок у виданні й робить його економічно ефективним.

Дослідження проводили у двох напрямках:

- перший - дослідження впливу характеристик шрифту на швидкість сприйняття та читабельність текстової інформації;

- другий - дослідження впливу характеристик шрифту на поліграфічне відтворення цифровим друком. 
Для проведення дослідження обрано п'ять гарнітур:

- три із засічками: Times New Roman, NewtonC, AcademyC;

- дві без засічок: FuturisC, Franklin Gothic Book.

Ці гарнітури обрані з огляду на їх часту вживаність (Times New Roman), замовлення видавництва, де проводилось дослідження (NewtonC), а також особливості накреслення - AcademyC (як можлива альтернатива часто вживаного Times New Roman).

Дослідження впливу характеристик шрифту на швидкість сприйняття та читабельність текстової інформації. Для дослідження підготовлено вісім текстових блоків однакової складності навчального характеру (джерело - Осічнюк Ю. В. Філософія). Обсяг текстової інформації містить 571-580 знаків. Оформлення текстових блоків проводили згідно зі сталими та змінними показниками, що наведені у табл. 1.
Вибір числових значень змінних характеристик зумовлений сприйняттям текстової інформації. Показники зміни трекінгу величиною більше -30, а зменшення ширини знаків більше ніж на 5 \% помітне для пересічного читача (неексперта у поліграфічній галузі). Тому зменшення значень масштабування на 2 \% і трекінгу $-10 €$ проміжними, відповідно до яких відбувається зміна оформлення текстового рядка так, щоб забезпечити збільшення обсягу текстової інформації без зміни обсягу видання або ж його зменшення.

Читабельність тексту досліджували за допомогою десятьох учасників віком від 21 до 30 років без вад зору. Експеримент проводили в умовах читання восьми пов'язаних за змістом текстів мовчки. Аналіз складності текстів проводився аналітично за допомогою обрахунку індексу Флеша (FRE - Flesch Reading Ease), адаптованого відповідно

Таблиця 1

Оформлення текстових блоків для дослідження впливу характеристик шрифту на швидкість сприйняття

та читабельність тексту

\begin{tabular}{|c|c|}
\hline Сталі характеристики & Змінні характеристики \\
\hline $\begin{array}{l}\text { - ширина колонки складання - } \\
\text { відповідно до формату 60×90/16, } \\
\text { перший тип оформлення }(117 \times 184 \\
\text { мм); } \\
\text { - кегль - 12; } \\
\text { - інтерліньяж - 14,4; } \\
\text { - накреслення світле, пряме }\end{array}$ & $\begin{array}{l}\text { - гарнітура; } \\
\text { - трекінг на величину - } 10 \text { та -30; } \\
\text { - масштабування символів по } \\
\text { горизонталі; } \\
\text { - зменшення ширини символу на } 2 \\
\text { \% і } 5 \text { \%; } \\
\text { - комбіновані: трекінг на величину } \\
\text {-10 та зменшення ширини символу } \\
\text { на } 2 \text { \%, трекінг на величину - } 10 \text { та } \\
\text { зменшення ширини символу на } 5 \text { \%, } \\
\text { трекінг на величину -30 та } \\
\text { зменшення ширини символу на } 2 \text { \% }\end{array}$ \\
\hline
\end{tabular}


до особливостей тексту українською мовою. Ці розрахунки проводили 3 метою дослідження рівноскладності обраних текстів. Індекс за шкалою FRES (Flesch Reading Ease Scale) розподіляється таким чином: 100 - дуже легко читається; 65 - проста мова; 30 - важко читати; 0 дуже важко читати. Значення 90-100 відповідає легкому тексту для молодших школярів; 40-70 - тексту, який можуть читати випускники школи; тексти з індексом 0-30 призначені для людей 3 вищою освітою. Відповідно до результатів обчислень - усі обрані тексти (вісім уривків) відповідають одній групі складності (достатньої легкості) і можуть вважатися рівнозначними (індекс FRE 50,175-59,345).

Зовнішні умови проведення дослідження уніфіковані - дослідження проводились за умов штучного місцевого освітлення 250 лк на відстані 40 см від очей. Для уникнення звикання до тексту, послідовність надання текстових блоків змінювали під час наступних вимірювань методом перекриття.

Час читання фіксувався за допомогою секундоміра (основний показник). Окрім того, кожен опитуваний дав оцінку читабельності шрифтів за п'ятибальною шкалою (додатковий показник), де оцінка 1 - легкість читання погана, а 5 - легкість читання висока.

На основі проведених досліджень можна стверджувати, що на читабельність найбільше впливає застосування комбінованих змін, а саме трекінг на величину -10 та зменшення ширини символу на $2 \%$, трекінг на величину -10 та зменшення ширини символу на $5 \%$, трекінг на величину -30 та зменшення ширини символу на 2 \% для всіх досліджуваних гарнітур.

Дослідження впливу характеристик шрифту на поліграфічне відтворення цифровим друком. Аналіз якості відтворення тексту проводили згідно з об'єктивними та суб'єктивними показниками. Об'єктивні показники ширина основного і з'єднувального штрихів (для рівноширинних шрифтів без засічок - лише основного) та різниця між їх фактичним значенням і значенням, закладеним у цифровому файлі. Суб'єктивні показники візуальна оцінка деформації штрихів літери, змазування та зникнення штрихових елементів (з'єднувальних штрихів, засічок).

Для проведення дослідження було створено тестові сторінки складання у програмному забезпеченні Adobe InDesign CS6 та Adobe Illustrator CS6. Для кожної $з$ гарнітур надруковано три примірника: один (однофарбовий) цифровою електрофотографічною машиною HP LaserJet Enterprise 600 M603n; два (один однофарбовий та один двофарбовий) струминним п'єзоелектричним принтером Epson L800. Двофарбовий відбиток містить текст, задрукований двома фарбами: $100 \%$ Cyan та $100 \%$ Yellow.

Друк проводили 3 роздільною здатністю 1200 dрі як для електрофотографічного, так і для струминного принтера. Папір для друку уніфікований для усіх зразків: фірма-виробник «HP Office Paper», мaca паперу $80 г / \mathrm{M}^{2}$, білизна - $168 \%$ CIE, непрозорість - $92 \%$, товщина 0,107 мм [9]. 
На тестових відбитках досліджували ширину штрихів згідно зі змінними характеристиками шрифтів, які наведено у табл. 1.

Вимірювання ширини штрихів виконували за допомогою електронного мікроскопа МОЦ-45, у таблиці заносили середнє арифметичне значення 3 трьох вимірів. Розрахунок відхилення фактичного значення ширини штриха на відбитку від закладеного у цифровому файлі та побудову графіків проводили у програмному забезпеченні MS Excel 2010.

За результатами аналізу відбитків можна зробити такі висновки:

- для гарнітур із засічками на відбитках струминного друку характерне значне спотворення штрихових елементів, зміна ширини сполучного штриха сягає 100 \% (за умови комбінації характеристик трекінг -30 та масштабування -2 \%). Форма засічок та межі штрихових елементів нечіткі, за умови значних величин стиснення відбувається злиття засічок сусідніх літер;

- для гарнітури AcademyC найбільше спотворення штрихів спостерігається у тексті зі зміною трекінгу на величину - 10 та -30. Спотворення за інших параметрів значні, використання масштабування та комбінованих параметрів недоцільні, форма засічок та межі штрихових елементів нечіткі, спостерігається переривання штрихів для кеглів $\leq 10$ п.;

- для гарнітур без засічок на відбитках струминного друку характерне спотворення штрихових елементів, яке не переви- щує $23 \%$, що означає кращу якість відтворення цих гарнітур порівняно з гарнітурами із засічками. Для струминного друку в дві фарби характерне невелике спотворення штрихових елементів. Текст розміру 12 п., задрукований «вивороткою» для шрифту FuturisC має найкращу візуальну оцінку. Найменше спотворення і відхилення спостерігається для зміни масштабування на $2 \%$;

- для зразків задрукованих електрофотографічним методом спостерігається незначна зміна величини штрихів для всіх гарнітур. За візуальною оцінкою деформація штрихових елементів відсутня, штрихи чіткі та безперервні;

- віддрукований вивороткою текст має більше спотворення, дещо деформований, штрихи перериваються, ширина штриха має значно менше значення порівняно зі значенням, закладеним у цифровому файлі;

- виявлено чітку тенденцію, що під час застосування комбінованих параметрів сполучний штрих зазнає більшого спотворення, ніж основний.

Загальні рекомендації щодо застосування зміни ширини символу та трекінгу наведено у табл. 2.

\section{Висновки}

Розроблено методику проведення дослідження, у якій вплив характеристик шрифтів досліджується двома основними етапами: дослідження читабельності та якості поліграфічного відтворення за умови зміни різних параметрів шрифтів. Читабельність визначалась за допомо- 


\section{Таблиця 2}

Рекомендації щодо застосування зміни характеристик шрифтів без втрат якості поліграфічної продукції

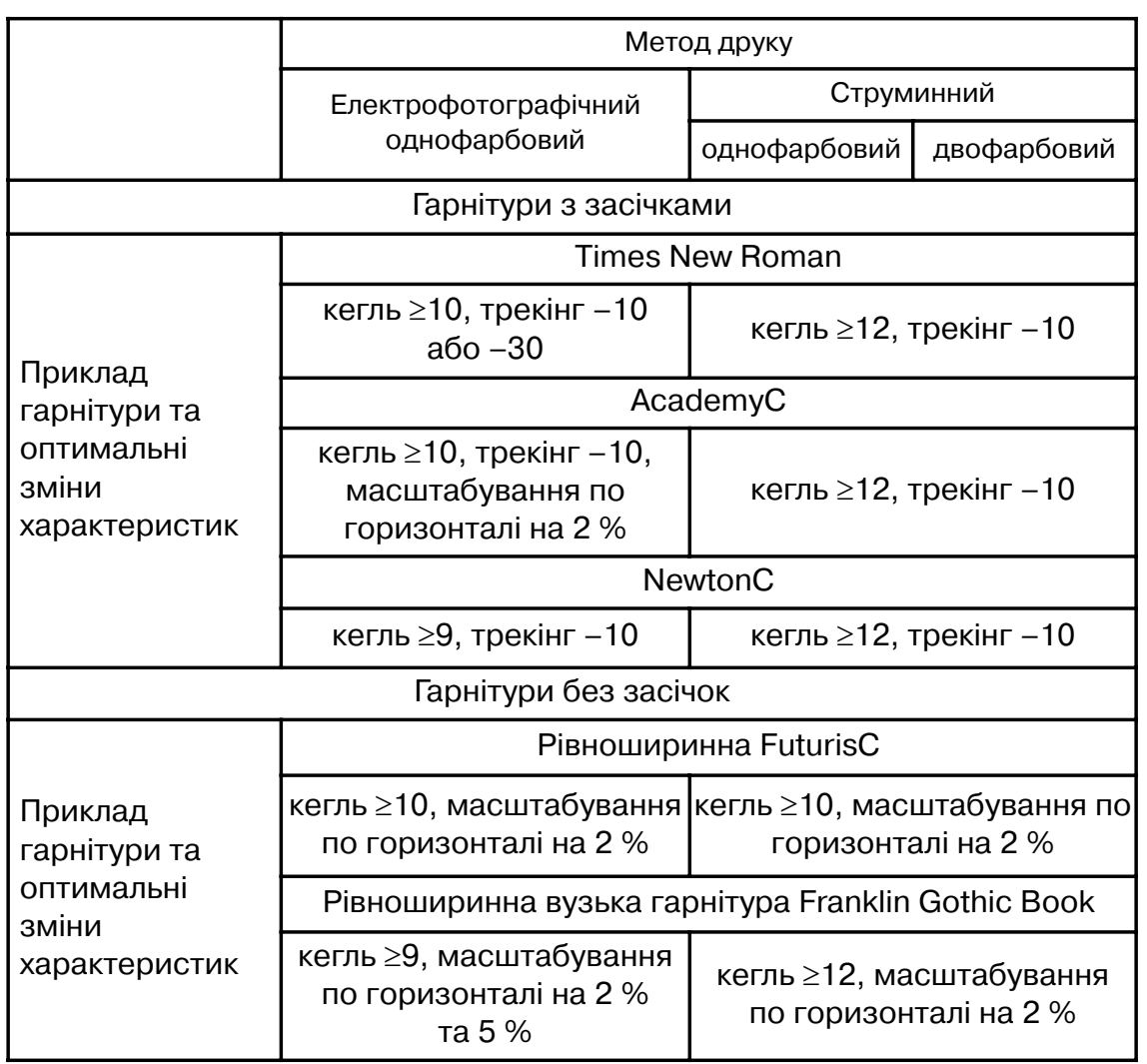

гою вимірювання часу читання тексту, а якість поліграфічного відтворення - за допомогою вимірювання спотворення основних та сполучних штрихів літери, а також оцінки деформації та спотворення штрихових елементів.
Результати проведених досліджень проаналізовано, на основі чого створено узагальнювальну таблицю рекомендацій щодо зміни параметрів шрифтового оформлення видання без втрати якості друкованої продукції.

\section{Список використаної літератури}

1. Петрик М. С. Зручність читання тексту / М. С. Петрик // Поліграфія і видавнича справа. 1999. № 35. С. 164-170.

2. Скільська У. Вплив параметрів шрифту на зручність його сприйняття / У. Скільська, Р. Теслюк, О. Хамула // Квалілогія книги. 2004. № 7. С. 39-46.

3. Токарь О. В. Технология оценки качества шрифта на допечатной стадии полиграфической підготовки / О. В. Токарь, М. А. Зильберглейт // Технологія і техніка друкарства. 2014. № 3(45). С. 30-35. Режим доступу: http://ttdruk.vpi.kpi.ua/article/view/36475/32650. 
4. Рогушина Ю. В. Использование критериев оценки удобочитаемости текста для поиска информации, соответствующей реальным потребностям пользователя / Ю. В. Рогушина // Пробл. програмув. 2007. № 3. С. 76-87. Библиогр.: 18 назв. рус.

5. Феличи Д. Типографика: шрифт, вёрстка, дизайн: Пер. с англ. и коммент: С. И. Пономаренко / Феличи Джеймс. СПб.: БХВ-Петербург, 2004. $496 \mathrm{c}$.

6. Токарь О. В. Построение ассоциативных правил на основе связи геометрических параметров шрифтов и объективной удобочитаемости / О. В. Токарь, М. А. Зильберглейт // Технологія і техніка друкарства. 2013. № 1(39). С. 40-46. Режим доступу: http://ttdruk.vpi.kpi.ua/article/ view/31046/27666.

7. Токарь О. В. Оценка восприятия печатных шрифтов / О. В. Токарь // Технологія і техніка друкарства. 2015. № 3(49). С. 39-46. Режим доступу: http://ttdruk.vpi.kpi.ua/article/view/54876/51007.

8. Токарь О. В. Взаимосвязь геометрических параметров шрифта и объективной и субъективной удобочитаемости / О. В. Токарь, М. А. Зильберглейт // Технологія і техніка друкарства. 2015. № 2(48). С. 47-54. Режим доступу: http://ttdruk.vpi.kpi.ua/article/view/48029.

9. HP Office Paper [Електронний ресурс] / Purelypaper. Режим доступу: http://purelypaper.co.uk/images/PDF/pp-hp-office-2013.pdf, вільний. 3 екрану. англ. мова.

\section{References}

1. Petryk, M. S. (1999). Zruchnist chytannia tekstu. Journal of Polihrafiia $i$ vydavnycha sprava, 35, 164-170 [in Ukrainian].

2. Skilska, U. \& Tesliuk, R. \& Khamula, O. (2004). Vplyv parametriv shryftu na zruchnist yoho spryiniattia. Journal of Kvalilohiia knyhy, 7, 39-46 [in Ukrainian].

3 Tokar', O. V. \& Zil'bergleyt, M. A. (2014). Tekhnologiya otsenki kachestva shrifta na dopechatnoy stadii poligraficheskoy pidgotovki. Journal of Tekhnolohiia i tekhnika drukarstva, 3(45), 30-35. Retrieved from http://ttdruk.vpi.kpi.ua/article/view/36475/32650 [in Russian].

4. Rogushina, Yu. V. (2007). Ispol'zovanie kriteriev otsenki udobochitaemosti teksta dlya poiska informatsii, sootvetstvuyushchey real'nym potrebnostyam pol'zovatelya. Journal of Probl. programuv., 3, 76-87 [in Russian].

5. Felichi, D. (2004). Tipografika: shrift, verstka, dizayn. Sankt-Peterburg: BKhV-Peterburg, 496 p. [in Russian].

6 Tokar', O. V. \& Zil'bergleyt, M. A. (2013). Postroenie assotsiativnykh pravil na osnove svyazi geometricheskikh parametrov shriftov i ob'ektivnoy udobochitaemosti. Journal of Tekhnolohiia i tekhnika drukarstva, 1(39), 40-46. Retrieved from http://ttdruk.vpi.kpi.ua/article/view/31046/27666 [in Russian].

7. Tokar', O. V. (2015). Otsenka vospriyatiya pechatnykh shriftov. Journal of Tekhnolohiia i tekhnika drukarstva, 3(49), 39-46. Retrieved from http://ttdruk.vpi.kpi.ua/article/view/54876/51007 [in Russian].

8. Tokar', O. V. \& Zil'bergleyt, M. A. (2015). Vzaimosvyaz' geometricheskikh parametrov shrifta i ob'ektivnoy i sub'ektivnoy udobochitaemosti. Journal of Tekhnolohiia i tekhnika drukarstva, 2(48), 47-54. Retrieved from http://ttdruk.vpi.kpi.ua/article/view/48029 [in Russian]. 
9. HP Office Paper. Journal of Purelypaper. Retrieved from http://purelypaper.co.uk/images/PDF/pp-hp-office-2013.pdf [in English].

\title{
Исследовано влияние изменения характеристик шрифта на качество воспроизведения текстовой информации цифровой печатью.
}

\begin{abstract}
Ключевые слова: характеристики шрифта; читабельность; показатели качества; трекинг; масштабирование символа по горизонтали; оригинал-макет.
\end{abstract}

Researched is the influence of the font characteristics changes on the quality of reproduction of text information printed applying the digital techniques.

Keywords: font characteristics; readability; quality; tracking; horizontal scaling of characters; layout. 